\title{
PENGEMBANGAN MODEL PEMBELAJARAN KEWIRAUSAHAAN BERBASIS PROYEK UNTUK MENUMBUHKAN SEMANGAT WIRAUSAHA MAHASISWA PRODI PENDIDIKAN EKONOMI IKIP PGRI BOJONEGORO
}

\author{
Eka Farida $^{1}$, Ery Tri Djatmika ${ }^{2}$, Bambang Banu Siswoyo $^{3}$, Mit Witjaksono ${ }^{4}$ \\ ${ }^{1234}$ Universitas Negeri Malang \\ email: feka46@yahoo.com
}

\begin{abstract}
ABSTRAK
Tujuan penelitian ini adalah (1) menyusun model pembelajaran kewirausahaan berbasis proyek dan (2) menguji efektifitas model pembelajaran kewirausahaan berbasis proyek untuk menumbuhkan semangat wirausaha mahasiswa pada program studi pendidikan ekonomi. Metode yang digunakan dalam penelitian adalah research \& development model DBR (Design Based Research) dari Reeves (2006). Hasil penelitian adalah (1) perbaikan model pembelajaran kewirausahaan dengan menyeimbangkan antara teori dan praktik, pembelajaran lebih diarahkan pada praktikum yang aplikatif, dan mewujudkan tujuan program studi yaitu menghasilkan lulusan yang memiliki semangat wirausaha; (2) pengembangan desain dan prototipe terdiri dari tiga komponen yaitu tujuan pembelajaran, metode pembelajaran, dan penilaian; (3) uji validasi oleh ahli pendidikan, kewirausahaan, dan uji terbatas menunjukkan tujuan pembelajaran, isi materi, dan sajian telah sesuai dengan konten/ isi, perwajahan, dan kebahasaan; (4) uji produk menggunakan kelas eksperimen yang ditentukan berdasarkan gaya belajar mahasiswa, mayoritas mahasiswa memiliki gaya belajar akomodator, hasil penilaian portofolio menunjukkan mahasiswa memiliki nilai sangat baik dan baik, produk yang dihasilkan oleh kelompok kerja mahasiswa sesuai dengan gaya belajar, dan uji keefektifan menunjukkan bahwa penerapan pembelajaran kewirausahaan berbasis proyek mampu menumbuhkan semangat wirausaha mahasiswa dengan sangat baik.
\end{abstract}

Kata kunci: kewirausahaan, pembelajaran berbasis proyek, semangat wirausaha

\section{PENDAHULUAN}

Semangat wirausaha memainkan peranan penting dalam dunia bisnis dan ekonomi. Saat ini, pemerintah dan intelektual menekankan pentingnya semangat kewirausahaan dikalangan mahasiswa. Mahasiswa sebagai salah satu kaum intelek dan tulang punggung reformasi di masa depan perlu membekali diri dengan semangat wirausaha. Mahasiswa ditantang untuk menciptakan lapangan pekerjaan sendiri dengan cara dan ide yang inovatif. Hal ini sesuai dengan ide yang dikemukakan oleh Aghajani \& Abbagholipour (2012) bahwa program pendidikan 
kewirausahaan di perguruan tinggi harus memperhatikan dan menumbuhkan semangat wirausaha.

Pendidikan kewirausahaan menjadi topik yang paling hangat dibicarakan, khususnya ditingkat perguruan tinggi. Hal ini disebabkan oleh munculnya beberapa permasalahan dalam pembelajaran kewirausahaan, diantaranya: (1) adanya ketidakseimbangan antara materi teori dan praktik ; (2) dosen belum menyadari pentingnya praktik kewirausahaan; (3) mahasiswa belum mampu menciptakan ide dan melirik peluang usaha yang ada di lingkungannya dikarenakan kurangnya pemahaman tentang praktik kewirausahaan; (4) proses pembelajaran kewirausahaan belum memanfaatkan peran stakeholder secara maksimal (Sarjono, 2012).

Perguruan tinggi memiliki tiga peranan penting dalam pendidikan kewirausahaan yaitu sebagai fasilitator budaya kewirausahaan, mediator keterampilan, dan lokomotif pengembangan bisnis regional (Edward \& Muir, 2005; Khan, 2008; Clouse, et.al, 2005). Pada hakikatnya, tujuan pendidikan kewirausahaan perguruan tinggi bukan sekedar mencetak pencari kerja, tetapi juga sebagai pencipta lapangan kerja (Fitriati, 2011; Wardoyo, 2012; Clouse, et.al., 2005; Aghajani \& Abbasgholipour, 2012; Susilo, 2014; Ekpoh \& Edet, 2011; Lee.at.al,2005).

Berdasarkan peran perguruan tinggi tersebut, upaya yang sesuai untuk menyelesaikan permasalahan pembelajaran adalah melalui model pembelajaran kewirausahaan berbasis proyek. Model ini menggambarkan sistem menanamkan kewirausahaan dalam berbagai disiplin ilmu, inovatif, dan menakankan belajar kontekstual melalaui kegiatan-kegiatan yang komplek (Clouse, et.al., 2005; Cord, 2001; Thomas, Mergendoller, \& Michaelson, 1999; Thomas, 2000; Gaer, 1998; Moursund; 1997). Upaya yang dilakukan untuk memperbaiki model pembelajaran kewirausahaan adalah dengan menerapkan model pengembangan DBR (Design Based Research).

Tujuan penelitian dan pengembangan ini adalah (1) menyusun model pembelajaran kewirausahaan berbasis proyek dan (2) menguji efektifitas model pembelajaran kewirausahaan berbasis proyek untuk menumbuhkan semangat 
wirausaha mahasiswa pada program studi S-1 pendidikan ekonomi FPIPS IKIP PGRI Bojonegoro.

\section{METODE}

Metode penelitian yang digunakan dalam penelitian ini adalah research \& development model DBR (Design Based Research) dari Reeves (2006). Collins (1992) menyatakan bahwa DBR merupakan metodologi yang penting untuk memahami bagaimana, kapan, dan mengapa inovasi pendidikan bekerja dalam praktiknya. Prosedur penelitian dan pengembangan dalam penelitian ini terdiri dari empat fase. Adapun langkah-langkah pengembangan model digambarkan sebagai berikut.

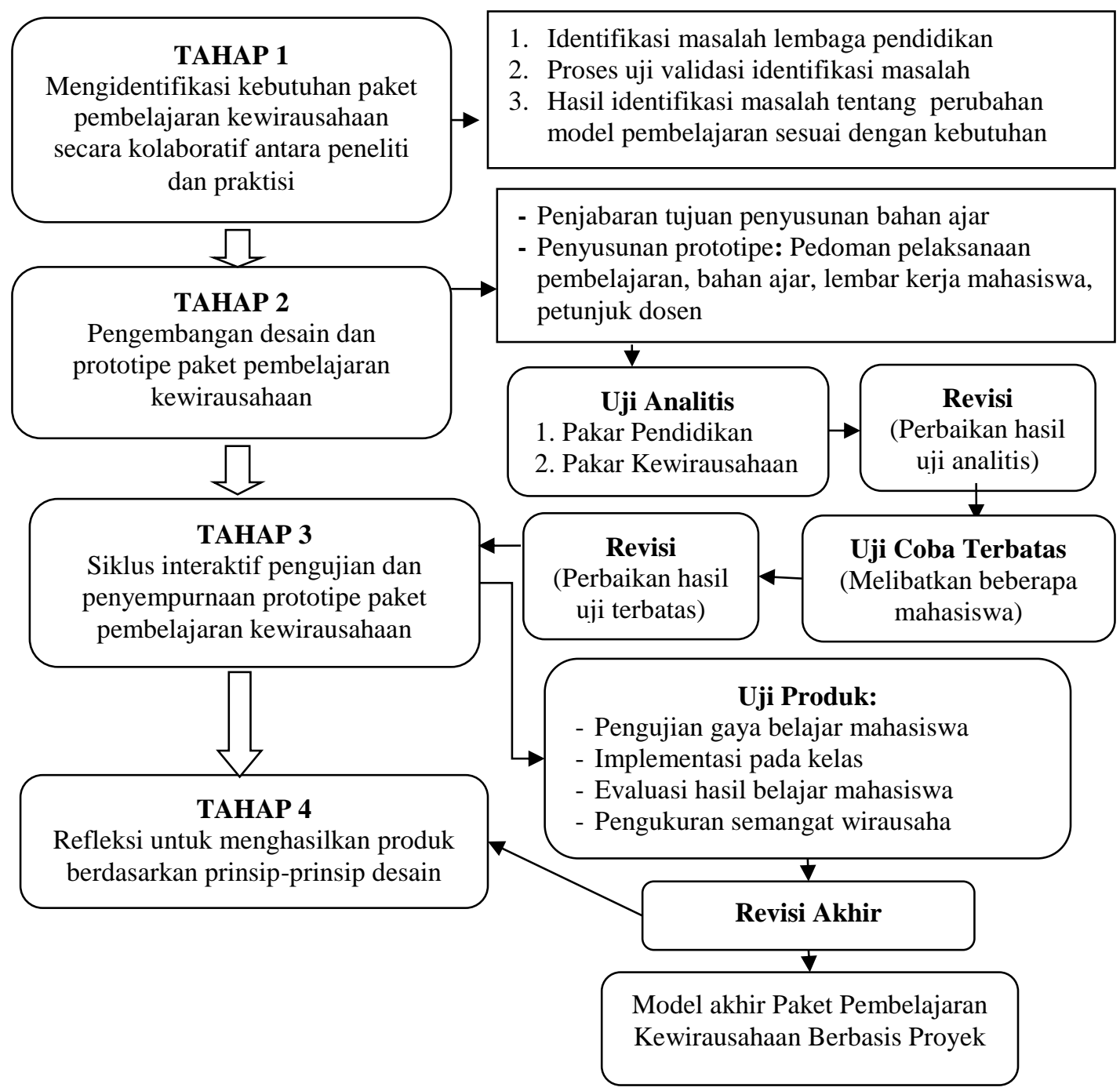

Gambar 1 Alur Penelitian dan Pengembangan 
Subjek penelitian adalah 36 mahasiswa program studi pendidikan ekonomi. Pengumpulan data dengan menggunakan metode observasi, portofolio, kuesioner, wawancara, dan FGD. Teknik analisis data yang digunakan adalah analisis kualitatif, persentase, dan uji beda (t-test).

\section{HASIL DAN PEMBAHASAN}

\section{Identifikasi dan Analisis Kebutuhan}

Hasil identifikasi masalah dan kebutuhan menunjukkan (1) latar belakang pemahaman mahasiswa tentang kewirausahaan menunjukkan sebesar 67\% mahasiswa memiliki pemahaman yang kurang; (2) penerapan kurikulum selama ini menunjukkan model pembelajaran yang digunakan masih terfokus pada teori dan belum diimbangi dengan kegiatan praktik; (3) perilaku dan sikap mahasiswa selama proses belajar mengajar kurang memanfaatkan waktu secara maksimal, motivasi belajar rendah, dan kurang disiplin waktu pada saat pembelajaran di kelas; (4) sikap dosen masih mendominasi kegiatan pembelajaran yang berdampak pada mahasiswa yang pasif dalam proses pembelajaran; (5) pembelajaran kewirausahaan yang diterapkan masih belum sesuai dengan visi program studi karena materi yang diajarkan belum mampu menumbuhkan semangat wirausaha secara maksimal; (6) harapan program studi, ada perbaikan model pembelajaran dimana mahasiswa dituntut lebih aktif dalam proses pembelajaran; (7) saran dan pendapat dari pihak terkait dalam FGD menyatakan sebaiknya pembelajaran lebih mengarah pada praktikum yang sifatnya aplikatif.

Berdasarkan penjabaran masalah di atas diperoleh identifikasi masalah tentang perubahan model pembelajaran sesuai dengan kebutuhan mahasiswa dan mampu mewujudkan visi program studi (Perpres 8/2012, KKNI; BSNP, SIPT 2010; SK Mendiknas No.45/U/2002). Analisis tujuan pembelajaran akan sangat menentukan secara tepat bentuk pengetahuan, keterampilan, dan sikap yang diharapkan sebagai hasil belajar (Moore, 2005; Reigeluth \& Merill, 1978). Mengacu pada tujuan ini, maka pembelajaran kewirausahaan berbasis proyek ditekankan pada internalisasi pengetahuan, pembentukan keterampilan dan sikap, sehingga tujuan ini cenderung mengarah pada tujuan orientasi prosedural dan 
pendukung prasyarat tentang langkah-langkah prosedur dalam melaksanakan kegiatan secara urut (Bloom, 1979; Gagne, 1977; Degeng, 2013).

\section{Hasil Pengembangan Desain dan Prototipe}

Bahan yang digunakan untuk menyusun desain model pembelajaran kewirausahaan antara lain: (1) mempertimbangkan latar belakang pemahaman mahasiswa tentang kewirausahaan; (2) latar belakang penerapan kurikulum yang selama ini dilaksanakan; (3) kebutuhan mahasiswa dan tujuan program studi pendidikan ekonomi; (4) kondisi perilaku belajar mahasiswa dalam proses belajar; (5) menggunakan desain terbalik (backward) dari Gagne dkk. (1992) yaitu menetapakan hasil belajar kemudian merumuskan tujuan, prosedur pembelajaran, dan evaluasi pembelajaran. Hasil pengembangan desain dan prototipe pembelajaran kewirausahaan berbasis proyek adalah sebagai berikut.

Tujuan pembelajaran meliputi (1) tujuan matakuliah yaitu memberikan wawasan baru tentang potensi wirausaha mahasiswa; (2) standar kompetensi yang ingin dicapai adalah mahasiswa mampu memiliki semangat wirausaha; (3) kompetensi dasar yang ingin dicapai adalah kemampuan mahasiswa menjelaskan peran dan pentingnya pendidikan kewirausahaan, mengembangkan imajinasi untuk menjadi seorang wirausaha, memiliki motivasi untuk mengembangkan wirausaha, menjelaskan karakteristik wirausaha, menemukan dan mengembangkan ide usaha, membuat perencanaan bisnis untuk usaha baaru, dan melakukan praktik kewirausahaan; (4) materi pokok dalam pembelajaran kewirausahaan terdiri dari peran dan pentingnya pendidikan kewirausahaan, membangun impian berwirausaha, mengembangkan motivasi berwirausaha, karakteristik wirausaha, menemukan dan mengembangkan ide usaha, perencanaan bisnis, dan implementasi bisnis.

Metode pembelajaran yang diterapkan meliputi pembagian kelompok kerja mahasiswa yang ditentukan berdasarkan gaya belajar mahasiswa (learning style inventory) yang diadopsi dari Kolb dan McCarty (1984) dan pembelajaran kewirausahaan berbasis proyek yang diadopsi dari The George Lucas Educational Foundation (2005). Penilaian didasarkan pada proses dan hasil pembelajaran kewirausahaan (portofolio dan produk). 


\section{Hasil Uji Coba Produk Awal}

Uji coba produk awal terdiri dari uji validasi ahli pendidikan, kewirausahaan, dan uji terbatas. Hasil uji validasi ahli dan uji terbatas ditunjukkan dalam tabel berikut.

Tabel 1. Hasil Uji Validasi Ahli dan Uji Terbatas

\begin{tabular}{lccc}
\hline \multicolumn{1}{c}{ Uraian } & Ahli Pendidikan & Ahli Kewirausahaan & Uji Terbatas \\
\hline Konten/ Isi & Baik & Baik & Baik \\
Perwajahan & Cukup baik & Baik & Baik \\
Kebahasaan & Baik & Sangat baik & Sangat baik \\
\hline
\end{tabular}

Sumber: angket penilaian paket pembelajaran kewirausahaan

Langkah selanjutnya setelah perbaikan produk awal adalah melakukan pengujian dan penyempurnaan prototipe paket pembelajaran kewirausahaan.

\section{Hasil Uji Coba Akhir}

1. Profil kelas uji model

Experential learning (Kolb, 1984) merupakan siklus yang harus dilalui untuk menentukan gaya belajar mahasiswa. Gaya belajar yang digunakan dalam pembelajaran ini adalah gaya pembelajaran akomodator dan asimilator. Penilaian gaya belajar mahasiswa secara akomodator dan asimilator memiliki relevansi terhadap pembelajaran kewirausahaan berbasis proyek. Penilaian gaya belajar akomodator dapat digunakan untuk menilai gaya belajar mahasiswa yang hanya mampu mengadopsi suatu produk yang sudah ada (sebatas teknik inovasi produk). Sedangkan gaya belajar asimilator dapat digunakan untuk menilai gaya belajar mahasiswa yang mampu menemukan ide baru sehingga dapat menghasilkan produk yang benar-benar baru. Hasil penilaian gaya belajar 36 mahasiswa menunjukkan bahwa sebagian besar mahasiswa memiliki gaya belajar akomodator. Sedangkan mahasiswa yang memiliki gaya belajar asimilator sebanyak 6 orang. Dari penilaian gaya belajar mahasiswa dan penerapan pembelajaran kewirausahaan berbasis proyek dapat menumbuhkan semangat wirausaha mahasiswa yang terdiri dari self directed, self nurturing, action-oriented, higly-energetic, dan tolerant of uncertainty. 
Gaya belajar mahasiswa memiliki relevansi dengan semangat wirausaha mahasiswa yang ditunjukkan dari dua dimensi pembelajaran yang dikembangkan oleh Kolb (1984) yaitu perceiving information dan processing information. Informasi yang diperoleh dan diproses akan menghasilkan suatu tindakan nyata sehingga berdampak pada sikap disiplin, percaya diri, keinginan untuk mewujudkan impian, memiliki energi yang tinggi untuk bekerja keras, dan siap dengan segala risiko yang akan dihadapi.

2. Penilaian portofolio dan produk

Produk yang dihasilkan oleh kelompok kerja mahasiswa sudah memiliki kesesuaian dengan gaya belajar mahasiswa. Gaya belajar akomodator ditunjukkan dengan kemampuan melakukan inovasi produk yang sudah ada yaitu bistik rarore, kripik waluh varian rasa, gethuk mlintir, bros kain perca dan pita, pisang selimut keju, ayam katsu, pisang kipas krispy, es buah moya, krupuk keong, dan es rujak cimut. Sedangkan gaya belajar asimilator ditunjukkan dengan kemampuan menemukan ide baru dan menghasilkan produk yang benar-benar baru yaitu pis la pas (produk makanan dengan bahan baku terbuat dari pisang dan ketela) dan aister mushroom gel (produk minuman dengan bahan dasar jamur tiram yang diolah menjadi agar-agar. Hasil penilaian portofolio menunjukkan sebanyak 16 orang mahasiswa atau sebesar 44,44\% memiliki nilai belajar yang sangat baik (nilai rata-rata portofolio 81-100), dan 20 orang atau sebesar $55,56 \%$ memiliki nilai belajar baik (nilai rata-rata portofolio 66-80). Dengan demikian dapat disimpulkan bahwa penerapan pembelajaran kewirausahaan berbasis proyek yang diadopsi dari The George Lucas Educational Foundation (2005) dan didukung oleh penentuan gaya belajar mahasiswa (Kolb, 1984) menunjukkan kemampuan mahasiswa dalam menentukan, merencanakan, dan melaksanakan proyek yang dipilih, sehingga hasil akhir dari pembelajaran ini sudah sesuai dengan harapan.

3. Semangat wirausaha

Penilaian semangat wirausaha mahasiswa didasarkan pada hasil penilaian kuesioner semangat wirausaha dan wawancara tentang pengalaman wirausaha saat mengikuti pembelajaraan kewirausahaan berbasis proyek. Dari 36 
mahasiswa yang telah mengikuti pembelajaran kewirausahaan berbasis proyek telah memiliki semangat wirausaha (spirit of entrepreneur) yang baik. Hal ini dapat dibuktikan dari penilaian kuesioner yang diberikan bahwa sebesar 51,9\% mahasiswa mampu menemukan dan mengembangkan ide usaha, 41,7\% mahasiswa mampu menjalin kerja sama yang baik, 65,28\% mahasiswa memiliki manajemen risiko bisnis yang baik, 65,74\% mahasiswa memiliki analisis bisnis baik secara internal maupun eksternal, 41,67\% mahasiswa memiliki sifat kerja keras dan keyakinan diri, 52,78\% mahasiswa mampu melakukan inovasi dan membuat produk yang kreatif, dan 52,78\% mahasiswa memiliki jiwa kepemimpinan yang baik. Berdasarkan hasil penilaian di atas dapat disimpulkan bahwa mahasiswa yang sudah menempuh matakuliah kewirausahaan berbasis proyek memiliki semangat wirausaha yang baik. Mereka mampu memiliki dan mengaplikasikan karakteristik sikap dan perilaku kewirausahaan yang berhasil (Zimmerer, 2002; Kasmir, 2007; Nickels, 2005; Lambing \& Kuehl, 2002).

4. Keefektifan pembelajaran kewirausahaan berbasis proyek untuk menumbuhkan semangat wirausaha mahasiswa

Berdasarkan penerapan pembelajaran kewirausahaan berbasis proyek, pembagian kelompok kerja mahasiswa sesuai dengan gaya belajar mahasiswa, penilaian portofolio dan produk yang dihasilkan telah mampu menumbuhkan semangat wirausaha mahasiswa dengan sangat baik.

\begin{tabular}{|c|c|c|c|c|c|}
\hline \multicolumn{6}{|c|}{ Coefficients $^{a}$} \\
\hline \multirow[b]{2}{*}{ Model } & \multicolumn{2}{|c|}{$\begin{array}{l}\text { Unstandardized } \\
\text { Coefficients }\end{array}$} & \multirow{2}{*}{\begin{tabular}{|c|}
$\begin{array}{c}\text { Standardized } \\
\text { Coefficients }\end{array}$ \\
Beta \\
\end{tabular}} & \multirow[b]{2}{*}{$\mathrm{t}$} & \multirow[b]{2}{*}{ Sig. } \\
\hline & B & Std. Error & & & \\
\hline 1 (Constant) & 24.043 & 21.993 & & 1.093 & .282 \\
\hline $\begin{array}{l}\text { Pembelajaran Kewirausahaan } \\
\text { Berbasis Proyek }\end{array}$ & .574 & .278 & .334 & 2.067 & .046 \\
\hline
\end{tabular}

a. Dependent Variable: Semangat Wirausaha

Secara uji statistika yang dilakukan juga menunjukkan nilai probabilitas sebesar 0,046 < 0,05 yang berarti pembelajaran kewirausahaan berbasis proyek dapat menumbuhkan semangat wirausaha mahasiswa. Dengan demikian, 
penerapan pendidikan kewirausahaan berbasis proyek merupakan strategi dan metode pengajaran yang tepat untuk meningkatkan intensi berwirausaha pada mahasiswa. Dengan meningkatnya intensi berwirausaha pada mahasiswa, maka semangat wirausaha mahasiswa akan tumbuh dan secara otomatis akan merubah pola pikir (mindset) mahasiswa dari pencari kerja menjadi pencipta kerja.

\section{Revisi Produk Akhir}

Revisi produk akhir yang dilakukan untuk perbaikan paket pembelajaran kewirausahaan meliputi (1) bahan ajar kewirausahaan dipisahkan dari lembar kerja mahasiswa; (2) lembar kerja mahasiswa sebagai rekaman hasil portofolio mahasiswa; (3) petunjuk pelaksanaan pembelajaran lebih difokuskan pada perencanaan dan pelaksanaan proses pembelajaran, serta penilaian hasil belajar; (4) dosen dibekali dengan buku petunjuk dosen sebagai rambu-rambu dalam menerapkaan pembelajaran kewirausahaan berbasis proyek.

\section{KESIMPULAN}

Hasil penelitian meliputi 4 (empat) hal berikut. (1) Identifikasi awal menunjukkan bahwa model pembelajaran kewirausahaan belum menyeimbangkan teori dan praktik, bersifat parsial, dan model pembelajaran belum mantap. Melalui penelitian ini telah disusun model pembelajaran dengan menerapkan pengembangan DBR yang menyeimbangkan teori dan praktik, praktikum yang komperhensif dan aplikatif; (2) Uji validasi oleh ahli pendidikan dan kewirausahaan, dan uji terbatas oleh responden menunjukkan bahwa tujuan, isi materi dan sajian pembelajaran dilihat dari konten dan perwajahan adalah baik, sedangkan dilihat dari perwajahan tergolong sangat baik; (3) Uji produk akhir menunjukkan bahwa gaya belajar mahasiswa mayoritas tergolong akomodator. Hasil penilaian portofolio mahasiswa sebagian besar tergolong baik. Produk yang dihasilkan kelompok kerja mahasiswa telah sesuai dengan gaya belajarnya. Uji efektifitas menunjukkan pembelajaran kewirausahaan berbasis proyek telah mampu menumbuhkan semangat wirausaha mahasiswa dengan sangat baik; (4) Revisi produk akhir dilakukan pada bagian: (a) bahan ajar yaitu memisahkan 
antara materi dengan lembar kerja mahasiswa; (b) petujuk pelaksanaan pembelajaran yaitu dengan menekankan pada perencanaan dan pelaksanaan proses, serta penilaian hasil pembelajaran; (c) disusun petunjuk dosen sebagai rambu-rambu penerapan pembelajaran.

\section{DAFTAR RUJUKAN}

Aghajani, H., \& Abbasqholipour, M. 2012. Explanation of Relationships between Biographical Characteristics and Entrepreneurship Spirit of Students. Iranian Journal of Management Studies (IJMS). Vol 5, No. 1, January 2012. Pp. 6378.

Bloom, B.S. 1979. Taxonomy of Educational Objective: Book1. Cognitive Domain. Landon: Longman Group Limited.

BSNP 2010 (Standar Isi Pendidikan Tinggi)

Clouse, R.W., Aniello, J., \& Biernaeki, J. 2005. A Problem-Based Learning Environment for Enginering Entrepreneurship. Prosiding of the 2005 American Society for Enginering Education Annual Conference \& Exposition.

Collins. 1992. Toward a Design Science of Education. In E. Scanion \& T. O'shea (Eds). New Direction in Educational Technology (pp. 15-22). New York: Springer-Verlag.

Cord. 2001. Contextual Learning Resource. Tersedia pada: http://www. cord.org/lev2.cfm/65. Diakses tanggal: 2 Maret 2001.

Degeng, I.N.S. 2013. Ilmu Pembelajaran: Klasifikasi Variabel Untuk Pengembangan Teori dan Penelitian. Aras Media.

Edwards, L.J. \& Muir, E.J. 2005. Promoting Entrepreneurship at The University Glamorgan Through Formal and Informal Learning. Journal of Small Business and Enterprise Development; 12, 4; ABI/INFORM Global, pg. 613.

Ekpoh, U.I., \& Edet, A.O. 2011. Entrepreneurship Education and Career Intentions of Testiary Education Student in Akwa Ibom and Cross River states, Nigeria. International Education Studies, Vol 4, No. 1; February 2011.

Fitriati, Rachma. 2011. Entrepreneurship Education: Toward Models in Several Indonesia's University. Prosiding The $4^{\text {th }}$ International Conference on Indonesia Studies: "Unity, Diversity and Future".

Gaer. 1998. Whats is Project-Based Learning? http://members.aol.com, diakses pada tanggal 7 September 2013.

Gagne, R.M. 1977. The Conditions of Learning (4th ed). New York: Holt, Rinehart, and Winston, Inc.

Gagne, R.M., \& Briggs, L.J., \& Wager.W.W. 1992. Principles of Instruction Design. New York: Holt, Rinehart and Winstone.

Kasmir. 2007. Kewirausahaan. Jakarta: PT Raja Grafindo.

Khan, S.A. 2007-2008. Entrepreneurship Education in Pakistani Universities. University of Essex Southend-on-Sea, School of Entrepreneurship and Business. 
Kolb, D.A. 1984. Learning Style Inventory Self Scoring Inventory and Interpretation Buuklt. Boston, NA: MCBER and Company.

Kolb, D.A. \& McCharty. 1984. GNVQ 7 Learning Style Inventory (adapted Kolb and McCharty). http://search?q=kolb+mccharty\&btnG=\&client., diakses pada 12 Januari 2013.

Lambing, P.A. \& Kuehl, C.R. 2002. Entrepreneurship. Second Edition. New Jersey: Prentice Hall.

Lee, S.M.,Chang, D., \& Lim, S.B. 2005. Impact of Entrepreneurship Education: A Comparative Study of The U.S. and Korea. International Entrepreneurship and Management Journal I, 27-43, 2005. Springer Science + Business Media, Inc. Manufactured in The United States.

Moore. 2005. Efective Instructional Strategies From Theory to Practice. London New Delhi: Sage Publication.

Moursund, D.G. 1997. The Feture of Information Technology in Education. http://darkwing.uoregon.edu/-moursund/books/futuresbook1997/index.html. diakses pada tanggal 1 januari 2013.

Nickels, W.G. 2005. Understanding Business. New York: McGraw-Hill.

Peraturan Presiden No. 8/2012 (Kerangka Kualifikasi Nasional Indonesia).

Reevers, T.C. 2006. Design Research from a Technology Perspective. In J.V.D. Akker, K. Gravemeijer, S. McKenney, \& N.Nieveen (Eds), Educational Design Research. Hlm. 52-66. London: Routledge.

Reigeluth, C.M. \& Meriill, M.D. 1978. A Knowladge Base for Improving Oue Methods of Instructional. Educational Psychologist, 13: 57-70.

Sarjono, dkk. 2012. Hasil Evaluasi Program Studi Kewirausahaan. IKIP , Bojonegoro. Tidak Dipublikasikan.

SK Mendiknas 045/U/2002 (Kurikulum Pendidikan Tinggi)

Susilo, W.H. 2014. An Entrepreneurial Mindset and factors Effect on Entrepreneurs Spirit in Indonesian. The SIJ Transactions on Industrial, Financial \& Business Management (IFBM), Vol. 2, No. 4, June 2014.

The George Lucas Educational Foundation. 2005. Instructional Module Project Based Learning. http://www.edutopia.org/modules/PBL/whatpbl.php., diakses pada tanggal 21 Januari 2012.

Thomas, J.W. 2000. A Review of Research on Project Based Learning. http://www.autodesk.com/, diakses pada tanggal 18 July 2013.

Thomas, JW, Mergendoller, JR \& Michaelson, A. 1999. Project Base Learning: A handbook of Midle and High School Teacher. Novato CA: The Buck Institute for Education.

Wardoyo. 2012. Pengaruh Pendidikan dan Karakteristik Kewirausahaan Terhadap Intensi Berwirausaha Mahasiswa Pada Perguruan Tinggi Swasta di Jakarta. Seminar Nasional Kewirausahaan dan Inovasi Bisnis II. Jakarta: Universitas Tarumanegara, 18 September 2012.

Zimmerer, T.W., and Scarbourg, Norman, M. 2002. Pengantar Kewirausahaan dan Manajemen Bisnis Kecil. Alih Bahasa Yanto Sidik Pratikno dan Edina Cahyaningsih Tarmidzi. Edisi 2. Jakarta: Prenhallindo 